\title{
Marcus Gunn jaw winking synkinesis: report of two cases
}

\author{
Kursat Bora Carman, Serhat Ozkan, Ayten Yakut, Arzu Ekici
}

Eskisehir Osmangazi University Hospital, Eskisehir, Turkey

\section{Correspondence to Dr Kursat Bora Carman, kbcarman@gmail.com}

\footnotetext{
To cite: Carman $\mathrm{KB}$, Ozkan S, Yakut A, et al. BMJ Case Reports Published online: [please include Day Month Year] doi:10.1136/ bcr-2012-008210
}

\section{SUMMARY}

Marcus Gunn jaw winking synkinesis (MGJWS) is caused by congenital miswiring of a branch of the fifth cranial nerve into the branch of the third cranial nerve supplying the levator muscle. It has been observed in $2-13 \%$ of patients with congenital ptosis. Although bilateral cases were reported, most were unilateral and occurred more frequently on the left side than the right. We report two cases of children who presented with ptosis and were diagnosed with MGJWS.

\section{BACKGROUND}

Marcus Gunn jaw winking synkinesis (MGJWS) was first described in 1883 as a unilateral ptosis with associated upper eyelid contraction and contraction of either the external or the internal pterygoid muscle. It is thought to occur because of congenital miswiring of a branch of the fifth cranial nerve into the branch of the third cranial nerve supplying the levator muscle. ${ }^{1}$ In previous reports, MGJWS has been observed in $2-13 \%$ of patients with congenital ptosis, and although bilateral cases were reported, most were unilateral and occurred more frequently on the left side than the right. ${ }^{2}$ Here we report the cases of two children who presented with ptosis and were diagnosed with MGJWS.

\section{CASE PRESENTATION \\ Case 1}

The case was of a 4-month-old girl who presented to a paediatric neurology clinic with ptosis of the right eyelid. Her parents reported that ptosis was noticed within a few days after her birth. She was born at 40 weeks of normal pregnancy from nonconsanguineous parents. She has no history of drug illness or orbital, facial or delivery trauma. A physical examination revealed that head circumference was $42 \mathrm{~cm}$, height was $60 \mathrm{~cm}$ (25th percentile) and weight was $6500 \mathrm{~g}$ (55th percentile). On physical examination, it was noticed that rhythmic elevation of the right eye consistently occurred when the infant sucked on a pacifier. The eye completely elevated with each suck and returned to normal alignment between sucks (video 1).

\section{Case 2}

The case was of a 6-year-old girl. She presented with ptosis of the left eye. Her previous medical history was unremarkable. A neurological examination revealed rhythmic elevation of the left eye with lateral movement of the mandible (video 2). The rest of the examination was normal.

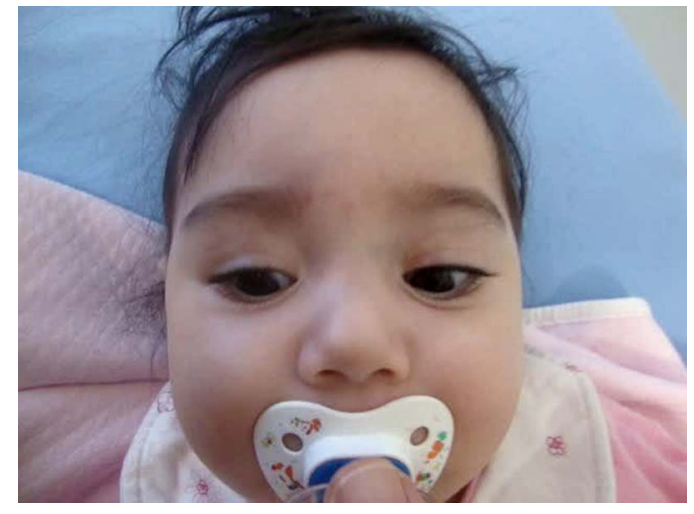

Video 1 The right upper eyelid completely elevated with each suck and returns to ptotic position with the end of sucking.

\section{INVESTIGATIONS}

Ophthalmological examinations in both cases showed normal external, anterior segment and posterior segment structures. Laboratory investigations of both cases revealed that complete blood count, blood urea nitrogen, serum creatinine, liver function tests, fasting blood sugar, serum electrolytes, serum uric acid, lactate, pyruvate, ammonia, erythrocyte sedimentation rate, $\mathrm{C}$ reactive protein, thyroid function tests and urinalysis were within normal limits. Brain MRI of both the patients showed normal anatomy.

\section{DIFFERENTIAL DIAGNOSIS}

Congenital ptosis.

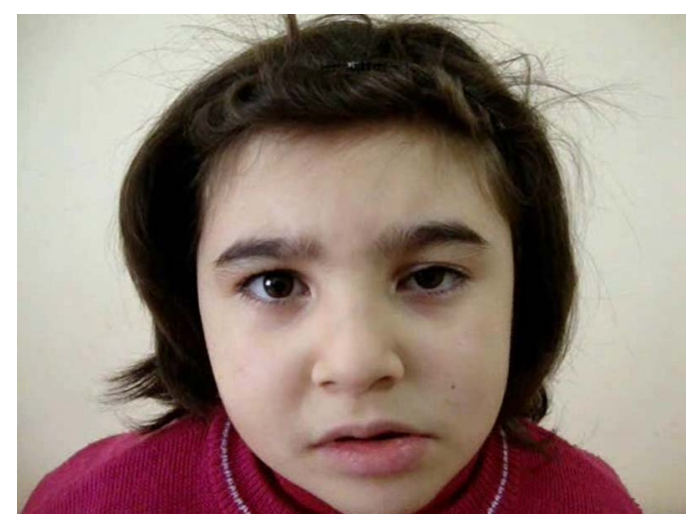

Video 2 The left upper eyelid completely elevated with lateral movement of the mandible and return to ptotic position with the end of movement. 


\section{TREATMENT}

No surgical operation was considered in either case.

\section{DISCUSSION}

In MGJWS, elevation and even retraction of the affected eyelid is triggered by chewing, suction, lateral mandible movement, smiling, sternocleidomastoid contraction, protruding tongue, Valsalva manoeuvre and even by breathing. ${ }^{3}$

Etiopathogenesis of MGJWS is not well defined. MGJWS is thought to occur from an abnormal branch of the trigeminal nerve, which has been congenitally misdirected in the oculomotor nerve supplying the levator muscle. ${ }^{3} 4$ The gestational age of the infant is not a predisposing factor for MGJWS. Koelsch and Harrington ${ }^{5}$ reported a full-term baby with MGJWS as in our case. However, premature patients have also been reported. ${ }^{4} 6$

The necessity for correction of the jaw wink is determined by the parent, patient and surgeon. In many children, the ptosis improves with time, but there is no scientific proof that this really does take place. It is believed that, as time passes, the affected individual will come to recognise which movements are responsible for the synkinesis and learn to control or avoid them and thus minimise or mask the syndrome. ${ }^{2} 7$

This report was carried out with the objective of alerting physicians to the existence of the MG phenomenon, which remains little known. In the differential diagnosis of patients with ptosis, MGJWS should be considered especially if it improves during feeding, sucking, chewing, smiling or any kind of mouth movement.

\section{Learning point}

- In the differential diagnosis of patients with ptosis, Marcus Gunn jaw synkinesis should be considered especially if it improves during feeding, sucking, chewing, smiling or any kind of mouth movement.

\section{Competing interests None.}

Patient consent Obtained.

Provenance and peer review Not commissioned; externally peer reviewed.

\section{REFERENCES}

1 Gunn RM. Congenital ptosis with peculiar associated movements of the affected lid. Trans Ophthalmol Soc UK 1883;3:283.

2 Doucet TW, Crawford JS. The quantification, natural course, and surgical results in 57 eyes with Marcus Gunn (jaw-winking) syndrome. Am J Ophthalmol 1981;92:702.

3 Torres MR, Calixto N Jr, Oliveira LR, et al. Marcus Gunn phenomenon: differential diagnosis of palpebral ptoses in children. J Pediatr 2004;80:249-52.

4 Ghodasra DH, Nallasamy $S$, Binenbaum G. Congenital trigemino-abducens synkinesis in a neonate. J AAPOS 2009;13:417-18.

5 Koelsch E, Harrington JW. Marcus Gunn Jaw-Winking synkinesis in a neonate. Mov Disord 2007;22:871-3.

6 Kassem IS, Kodsi SR. Marcus Gunn jaw winking with trigemino-oculomotor synkinesis of the inferior division of the oculomotor nerve. J AAPOS 2009;13:315-16.

7 Demirci H, Frueh BR, Nelson CC. Marcus Gunn jaw-winking synkinesis: clinical features and management. Ophthalmology 2010;117:1447-52.

Copyright 2013 BMJ Publishing Group. All rights reserved. For permission to reuse any of this content visit http://group.bmj.com/group/rights-licensing/permissions.

BMJ Case Report Fellows may re-use this article for personal use and teaching without any further permission.

Become a Fellow of BMJ Case Reports today and you can:

- Submit as many cases as you like

- Enjoy fast sympathetic peer review and rapid publication of accepted articles

- Access all the published articles

- Re-use any of the published material for personal use and teaching without further permission

For information on Institutional Fellowships contact consortiasales@bmjgroup.com

Visit casereports.bmj.com for more articles like this and to become a Fellow 